\title{
"EKOROLËV" - DIMENSIONS IN URBAN AND COUNTRYSIDE PLANNING OF SUSTAINABLE DEVELOPMENT
}

\author{
Kavtaradze Dmitry N. \\ Full Professor of the Lomonosov Moscow State University, \\ School of Public Administration. \\ Address: \\ E-mail: kavtaradze@spa.msu.ru

\section{Casu Alessandra} \\ $\mathrm{PhD}$, Researcher and Teacher of Urban Design and Urban Sustainability \\ at the University of Sassari, Department of Architecture. \\ Address: University of Sassari. Palazzo del Pou Salit, \\ Piazza Duomo 6, I-07041, Alghero (SS0), Italia \\ E-mail: casual@uniss.it
}

\begin{abstract}
To provide sustainable development (and not just growth) of urban areas, experts and regional authorities should jointly follow the principles of Sustainable Development (SD) that were originally proposed by the fundamental work Limits to Growth (Meadows et al., 1972) which described global, national and inter-regional strategies, plans and dynamics for urban development. As a result of SD, a new (more sustainable) type of urban strategy, ecopolis strategy, can be proposed.

We will present an example of such an urban ecopolis strategy. It was elaborated for Moscow Region city Korolëv, combining architecture, planning and design, ecosystem restoration, evaluation of risks and calculation of resources required for strategy implementation. The ecopolis strategy for Korolëv city ("E Korolëv project") was produced over several years by a special task force - a joint Italian and Russian team along with the city council of Korolëv (Kavtaradze, Casu, 2011) - which concentrated the project around key elements of ecopolis strategy, as described in the article.
\end{abstract}

Keywords: sustainable development; environmental project; risk management; urban regeneration; ecological networks

\section{Introduction: Approaches to Sustainability}

\section{Approaches to Sustainability: EcoPolis}

The "ecopolis" concept was elaborated in the 1980s as an application of the theory on "Coherent Development of Nature and Society" (Brudny, Kavtaradze, 1981; 1985). Ecopolis is a town and immediate surroundings where humans and ecosystems are coherent with nature. Fragments of Ecopolis are recognisa- 
ble in many cultural landscapes and towns as green areas, urban forests, brooks and channels. Ecopolis is a wishful human settlement of the future whose ecological parameters are controlled and whose inhabitants are prepared for constant change, in both mode of life style and nature. Large-scale research and an experiment on the mutual adaptation of man and nature have been taking place in Poushkino (Moscow region) since 1980 with the in-depth participation of local citizens and town's administration. In many cases, when describing eco-cities in practice, in different continents and countries, difficulties arise in finding any scientific background to the projects - besides taking care of city's metabolism, air and water quality, and energy saving by means of urban planning. This approach, which started in the 1980s, has been published and discussed many times (Sukopp, Henke, 1988; Numata, 1988; Deelstra, 1988). As far as we know, the "Ecopolis concept" was not developed or implemented into international practice, even after several reports on international conferences and two World Exhibitions (Tzukuba, Brisben). Nevertheless, space design and ecological research took place in Russia at Krasnoyarsk laboratory, and the "Biosphere2" large-scale experiment in Arizona was heavily supported by the Ecotechnics Institute in London, whose support still continues today. So called eco-settlements are popular in modern Russia and mainly operate without any academically correct science reference or research, and only by using organic farming and traditional agriculture activity in comparatively small communities (Gerzberg, 2015).

\section{Coherent Development of Nature and Society as the SD concept of Ecopolis}

In Russian science it is customary to refer to the world famous philosopher, thinker and natural scientist Vladimir Vernadsky. His theory on the biosphere was one of the key steps in applying his concept to reviews and improvement in planning. The term "ecopolis" (Brudny, Kavtaradze, 1981) covers the historical experience of previous policies and imparts a practical modern vision of our vital dependence on biosphere conditions and the functioning of non-replaceable ecosystems.

The "sustainability" catch-all title has lately become part of the lexicon of the environmental project (and, not surprisingly, in the original meaning of the verb to sustain) proposed by the School of Architecture at Alghero (Sardinia, Italy), often referred to in a descending scale, particularly in architectural dimension and construction, or in qualitative and quantitative methods. However, within the features of this genre it is still possible to find, particularly in the "non- negotiability" of environmental values, both natural and human, a search for "strong" sustainability, in the sense given by Herman Daly $(1990,1992)$ of non-substitutability of natural capital by "artificial" (human, social and economic) capital: the sum of natural and anthropogenic capital can be kept at a constant value, or each component can be kept constant. The first approach is reasonable if we think that the two types of capital are interchangeable with each other. The second point of view is reasonable if we think that natural and man-made capital are complementary. Both sides must therefore be maintained intact (separately or jointly, but with fixed propor- 
tions) because the productivity of one depends on the availability of the other. The first approach is called "weak sustainability", the second "strong sustainability” (Daly, 1977, 1996).

Theoretical and applied research, and project teaching, address the relationship between population, activities and places, highlighting the limits of resources - renewable or not - through a critique of the approaches used by the so-called Ecological Economics (de Jouvenel, 1965; Boulding, 1966; Knees et al., 1970; Beckerman, 1972; Georgescu Roegen, 1972; Dasgupta and Heal, 1979; Pearce and Kerry Turner, 1990; Costanza, 1991; Martinez Alier and Schlupmann, 1991; Immler, 1993, Ruth, 1993; Vivien, 1994; Grossman and Krueger, 1995; Daly, 1996; Solow and Stiglitz, 1997; Linton, 1998; Munasinghe, 1999; Pigou, 1999; Passet, 1996, 2000; Martinez Jusmet Alier and Roca, 2000; Kavtaradze, Likhacheva, 2012; Gagarina et al., 2015). Criticism of the established models will appeal as much to claim non-substitutability of resources (Daly, 1996), as the potential and limitation of approaches based on the carrying capacity (Hui, 2006; Sayre, 2008) or on the "footprint" due to lifestyles (Wackernagel and Rees, 1995; Chambers et al., 2001). The strands of applied research and teaching at Alghero, not necessarily channeled into any project, move mainly along two complementary and not necessarily alternative lines: one project is aimed at reducing energy and scarce resources (water, soil) consumption. The other research project aims to a different, more complex "measure" of the sustainability of choices, policies, plans or projects, by using decision support systems for the assessment of different alternatives.

The first strand of teaching and research, which unfolds in collaboration with local institutions, moves from a review of a local building tradition that does not focus on formal or stylistic features but, rather, on "environmental reasons" of settlements, their role of mediating energy and their bioclimatic function (Spanedda and Serra, 2007; Bulla et al., 2012) systems, identifying routes of development and regeneration of dwellings (Norberg-Schulz, 1995) which may be based on these aspects. This exploratory path is project-oriented and is also accompanied by educational and research activities related to:

- energy production from renewable sources (Delitala et al., 2001; Arnulfo and Marini, 2010; Gazzano et al., 2010);

- the recovery of construction traditions with low environmental impact (Bacchini et al., 2012);

- the development of eco-friendly and durable building materials with a more sustainable lifecycle.

The second strand, which moves sometimes in parallel to and sometimes jointly with the first, at times by the same people, has been investigating the assessment of design and planning options according to established disciplinary guidelines but also improving them with innovative proposals. One first example is the testing of a variant of the ecological footprint $a$ la Wackernagel, applied to the settlement choices related to tourist flows, whose developments have led to the proposition of some original models of interaction between tourist populations and territories (Cecchini, 2009), and - especially in doctoral dissertations - the expansion of some methods, algorithms and proce- 
dures for the assessment of the effects of tourist flows on the urban fabric, the landscape and the environment: from the critical analysis of some sets of urban sustainability indicators (Antonini, 2010), to proposals for their integration with the effects of tourist flows on historical urban fabric and some indicators of use of environmental services (Antonini and Cecchini, 2009; Antonini, 2010), to a critical reading of the trivialization (Muñoz, 2004) in the built landscape induced by collective images related to tourism, to the attempt to measure the relationship between tourist populations and territories (Cannaos, 2010).

This attempt to investigate soft aspects, which are more difficult to measure in terms of the relationship among people, activities and places, then sees a fruitful line of research in the application of the social dimension of sustainability, according to the capability approach proposed by Martha Nussbaum and Amartya Sen (1993, 1999; Nussbaum, 1999; Phipps, 2002; Clark, 2006) and applied to the evaluation of the quality of inhabited places, starting with the most vulnerable populations (Blecic et al., 2013), which promoted further research along the same lines, though more oriented towards so-called social capital. The latter has developed another peculiar variation: public participation in decisionmaking and assessment which is being pursued both in educational and in field activities, both in theoretical and applied research (Casu, 2013; Plaisant, 2013), both in helping local territories in planning, urban regeneration, and also with the production of ad hoc tools for online interaction. This research is not limited to "work with people" by searching for their empowerment (Friedmann, 1992), but also seeks to explore implicit, latent design scenarios, relevant to self- and hetero- representations and images of the territory by its different kinds of population (Pittaluga, 2008).

These lines of research and action come together and intersect with the approaches of sustainability-oriented policies which aim to tackle climate change, facing, on one hand, mitigation of the effects and, on the other, the adaptation to change. One case of the first type is represented by the aforementioned strategies of bioclimatic design, intended to reduce greenhouse gas emissions in the atmosphere and reduce the phenomenon of so-called urban heat island (Oke, 1973). A case of the second type is offered by the responses to climate change - that, in terms of land and urban policies, are inevitably different according to their geographical, but especially financial, contexts that can offer new variations taken by the design and planning choices in consideration of the so-called "urban metabolism" (Blecic et al., 2011) or ways of dealing with the probable increase of the water level (e.g. the Sustainable Urban Drainage System: Butler and Parkinson, 1997): a set of search paths currently still in progress.

The latter horizon explored by the research - the impact on the man-made environment by climatic factors and their particular consequences, leads to an issue that in recent years has resulted in different attitudes to planning, which now include the issues related to risk and hazard. This has led to the development of research: on the one hand in the direction of modeling, simulation and a better interpretation of phenomena (Trunfio, 2004; D’Ambrosio et al., 2006; 
D'Ambrosio et al., 2012) and, secondly, towards constructing an awareness of the environmental risk more widely felt and extended to local societies, including through intensive training programs, involving actors, institutions and other territories, involved and upset by natural disasters.

Only in very recent years environmental risk has started to be discussed in accordance with ecosystem conditions and their carrying capacity. What should be avoided is that theory continues to be separate from large scale experiments, likewise practical planning with continuing long term monitoring. To sum up, the present description of the basic principles of SD should include:

- taking into account climate changes and mitigation consequences through urban planning;

- shifting projects to marine and aquatic systems, including underwater settlements;

- taking into account biodiversity and environmental issues based on field ecology;

- Use of IT systems and simulation modeling of the metabolism of highly urbanized territories.

This short and reliable non-exhaustive list of teaching, research and lines of action is witness to the program which led to an ethics of places related to each other, and to the communities that inhabit them (Norberg-Schulz, 1985), in a continuous process that gives rise to a shared notion of territory.

International conferences show the main urban planning groups' interest in applying ecology as a form of landscape planning and design. These experiences often see the productive cooperation of soil scientists, ecologists and sociologists, in some way. Real multidisciplinary cooperation is recognizable in the environmental project. At first glance, the key points of the environmental project appear to correspond to those of Landscape Urbanism (Russell, 2001; Mostafavi, 2004; Waldheim, 2006), especially in the pursuit of an environmental structure as a generative structure, and in the project to lead the evolutionary process. The environmental project is characterized according to some recurring themes, especially in relation to teaching experience (Casu, 2011), that are easily recognizable in the Ekorolëv project:

- ecological and socio-territorial contextualization: so the design exploration is less attentive to seek its formal character when searching for nature and history signs to define the general pattern, and looking for consistency until the design of the individual elements of the structure;

- orientation to the process, rather than to the form (Tiallingij, 2000), which facilitates inter-scalar relations;

- processuality, for which the form is given by the succession of temporary steady states (Daly, 1977; Pigou, 1999), whereby

- priority to the public and social dimension of spaces;

- constraint as an opportunity for the project;

- synthesis of ecology, landscape, urban planning, infrastructureand architecture;

- intervention in edge areas, in transition between different environmental and settlement situations (Tiallingij, 2000): the main objective is therefore 
to overcome the bio-geographical, functional, social conditions of isolation and consequent fragmentation.

These characters would also imply reversibility with respect to any stationary configuration: a goal that can only be approached in a search for being "light on the earth" and containing the footprint (Wackernagel and Rees, 1995; Chambers et al., 2001; Kavtaradze, Lychkina, Volkov, 2010; Kavtaradze, 2015) on the environment.

In a new Russian magazine about Attractive Urban and Rural Landscapes, URBAN, best practices are shown in terms of good places for people, or "green" places: sometimes articles only discuss the results in terms of moving grass in cities (Ignatieva, Ahrné, 2013). We need to underline that ecosystem theory as an academic discipline is slowly penetrating practice.

\section{Towards a more Ecological Korolëv}

With financial aid from the Italian Minister of Education and Korolëv Institute of Management, Economics and Sociology, the School of Public Administration at the Lomonosov Moscow University, together with the former Department of Architecture and Planning at the University of Sassari, proposed a two-year cooperation and student exchange program. An inter-active format was chosen, consisting of intensive Summer Schools: planning and design workshops interbedded with 'expert' seminars, simulation sessions, games and role play, field trips, and cultural interchanges. The program provided one intensive Summer School that took place in Korolëv, and another intensive Summer School in the context of the Sardinian Geo-Mining Park. Both Schools shared some planning and design topics and devices (e.g.: soil, water and air pollution; systems of phyto-remediation; brown fields and wastelands reuse), in a general framework of Sustainable Development that inverted its scales and paradigms. In Korolëv the project was developed at an urban scale, and inserted into the general ecological network; in Sardinia a network of places was the starting point and the environmental issues (e.g.: mobility, land reclamation, blue and urban green infrastructures) were treated in a more detailed scale.

The project was multidisciplinary in several dimensions:

- Scientific and educational practice;

- Latin and Slavic cultural cooperation in research and project;

- Jointly organized field studies, art interpretation and IT as an everyday instrument of planning and decision making;

- The result was tangible and presented: both to officials of Korolëv town and published (Kavtaradze, Casu, 2011) and to the Geo-Mining Park Authorities.

- The international team work gave produced educational results and the project wa being a mode of cooperation.

- The initiative of university professors was positive and used later in different local projects by repeating some of the information. Several years have now passed and Ecological Korolëv has become an innovative project for local architects and for other sustainable development plans to be released. 


\section{Developing a desirable future EKorolëv science-city}

A "city of the future" design is demonstrated in many student competitions as well asnational and international architect exhibitions. Looking through old English, French and Russian magazines it is difficult to find any case of their implementation after 10,20,50 years. It seems to be a professional exercise only. Ecological Korolëv is also an intellectual model (look above) that is positively based on successfully recognized (natural, social) barriers, that in the project were often overcome. Among them are long term working restrictions: the risks of which could be relevant many years later; restrictions that come from the type of landscape, ecosystem dynamics, human needs etc. and reveal themselves decades later. It seems to be the main role of science and field work: recognize value and avoid conflict between artificial and natural ecosystems.

For project participants and educators it looks similar to first steam automobile, that is moving so slowly and noisily that it kills any imagination that it will have a fantastic future.

To be certain in our underlying result we need to mention some important points.

- Korolëv town was a really good opportunity to begin with. Very well educated citizens, advanced administration, world famous space technologies: the right place to start a multidisciplinary project from scratch in cooperation with the best universities.

- SD principles suit Korolëv as a complex that combines intellectual, engineering and advance space philosophy and technologies: citizens are motivated to try new approaches and are ready to be involved in experiments.

- Korolëv is a potentially perfect "ecologically friendly city", due to its situation across the direct boundaries of "Losiniy Ostrov" National Park and near the biggest megapolis. The importance of this natural neighbor requires further comment.

Korolëv is situated on a moraine-water-glacier plain and part of Meshchera physiographic province that occupies the eastern part of Moscow region. The climate is characterized by moderate cold winters and warm summers. The town's population is more than 172,000 people. Today Korolëv has the status of 'science city' (awarded on 12 April 2001). The city occupies 52 square kilometers. It is a center for the rocket-space industry. The city is bounded by other towns: Mytishchi, Pushkino, Fryazino, Shchelrovo and the city of Moscow. The southern boundary is formed by "Losiniy Ostrov" National Park.

"Losiniy Ostrov" is the biggest National Park in the vicinity of a megapolis and occupies a territory of 11,816,000 hectares. Moscow Ring Road passes through its territory for 7.5 kilometers, dividing it into urban and regional parts. The flora and fauna is very rich: 45 mammal species, 185 birds, 9 amphibians and no less than 20 fish species. Many of the flora and fauna species of the National Park are included in Russian national and regional Red Data Books.

It became clear that our project would encounter several universal problems of SD so we established: meaningful communication "bridges" that opened up the possibilities for mutual understanding; reciprocal communication be- 
tween scientists, municipal administration, planners, National Park authorities and Korolëv Technological University. Then we are able to work together.

It is extremely important to work in a $3 \mathrm{D}$ real environment particularly as each suggestion requires an immediate answer to several certain questions: why, where and what will happen in several years. Answers need to be drawn on paper and recognized on screen. Multidisciplinary projects are the result of intensive team work, by a team that is working together for many days, shoulder to shoulder, in the same few rooms, and traveling and even cooking together etc. Then there are the discussions, though not arguing. We think that Korolëvscience city as a polygon and the EKorolëv project are a valid example of steps in the right direction and a method of project design that needs to be qualified. An Italian planners' vision of landscape, ecosystems and social network was productively presented by Alessandra Casu along with fully implemented scientific data from long term research conducted by the city's ecologist Vladimir Volkov.

In Korolëv six "principles" for a more sustainable development were proposed, each one calling for a system of actions to implement ecological planning, and aiming to reach the implicit objectives that each principle intended. According to the original notion of SD, the principles, their objectives, and the related actions propose a strategic approach that tries to make ecological, economic and human aspects work together (Tab.).

Table

\section{Scheme of principles for local EKorolëv SD and related actions}

\begin{tabular}{|c|c|}
\hline $\begin{array}{c}6 \text { principles of sustainable } \\
\text { development }\end{array}$ & $\begin{array}{l}\text { Actions to implement } \\
\text { ecological planning }\end{array}$ \\
\hline Save and improve ecological network & $\begin{array}{l}\text { Maintain the ecological infrastructure at all scales. } \\
\text { Policies for Ecological Connectivity at Different Levels } \\
\text { Projects to Mitigate Landscape Fragmentation }\end{array}$ \\
\hline $\begin{array}{l}\text { Closing the Cycles: Environmental } \\
\text { resources management }\end{array}$ & $\begin{array}{l}\text { Prevent flooding } \\
\text { Provide New Recreational Places } \\
\text { Complete Water and Waste Cycles }\end{array}$ \\
\hline Natural resources management & $\begin{array}{l}\text { Maintain the Reserves } \\
\text { Provide opportunities for Education \& Recreation } \\
\text { Organize the Activity at Different Scales }\end{array}$ \\
\hline Edge design & $\begin{array}{l}\text { Manage the Transition from Urban to Country and Nature } \\
\text { Reuse Abandoned, Residual, and Waste-lands } \\
\text { Establish Urban Agriculture }\end{array}$ \\
\hline Sustainable Housing & $\begin{array}{l}\text { Save Resources with Smart Buildings } \\
\text { Reuse Abounded Buildings for Collective activities } \\
\text { Balance Density and Social Needs }\end{array}$ \\
\hline Risk management & $\begin{array}{l}\text { Policy of Land-Use to prevent Hydro-geological Risk } \\
\text { Save Public Health by managing Ecological Resources } \\
\text { Manage the Industrial Risk }\end{array}$ \\
\hline
\end{tabular}


On closer inspection of the proposed principles, some implicit objectives and disciplinary topics emerge:

- Save and improve ecological network means the recognition of the environmental structure of the place, and claims for actions aiming to maintain it, facing the fragmentation and improving the connectivity.

- Closing the Cycles: Environmental resources management recalls the need for an adequate management of scarce resources, in a sort of symbiosis among people and environment, where this can also provide places for implementing a new, better "sociability". Actions are mostly related to the management of rain and storm water, and to the lifecycle of the "second matters".

- Natural resources management: the Natural Park is shared by Korolëv and the Moscow Metro Region. Along its edges, anthropogenic pressure is threatening the natural resources and their maintenance; at the same time, the lack of recreational and educational places can threaten even more by increasing anthropogenic pressure on the environment, calling for actions that can balance these antagonistic needs.

- Edge design faces the transition between urban and rural, urban and natural, by interposing forms of buffer zones in which each function is gradually included and "absorbed" by the ecosystem.

- Sustainable Housing not only calls for the need to avoid soil consumption by regenerating wastelands, brownfields, neglected or abandoned areas: it also calls for a stormwater drainage system to provide new recreational areas, and design devices to save energy and scarce resources, and to avoid monotony in housing by balancing density and social needs.

- Risk management faces either adaptation to flooding and the management of stormwater or industrial risk (many factories related to aero-spatial and military technologies are located in Korolëv) and consequent nano-particle pollution.

Implementation of the EKorolëv project might have a different strategy and tactics. The most reasonable in given conditions is to improve certain places and elements that are meaningful and coherent with the whole project, and can be implemented by the city's Green service. Also, the highways were improved and have taken a part of the traffic load from the national park. One attractive proposal by EKorolëv was to create a recreational area on the Green space over the covered water supply channel. Though even a good project is not easy to implement in a living city. It is well known that the municipal government usually has independent tactics and important tasks that should be done tomorrow. This explains the importance of the small scathes' figures in our article as it is language of the project. Words are good to give names to principles and pictures to demonstrate options of their implementation.

The six principles, and the actions to implement them, match together in a sort of Strategic Master Plan (Fig.) that shows their localization and how they can match and work together.

The Master Plan is accompanied and better detailed with other visuals, in which every single idea is represented by sketches, graphics, photo-simulations and suggestions. For the public audience a PPT presentation was also provided, helping with images, slides and animations. 
Figure

\section{Original cover for the EKorolëv SD project}

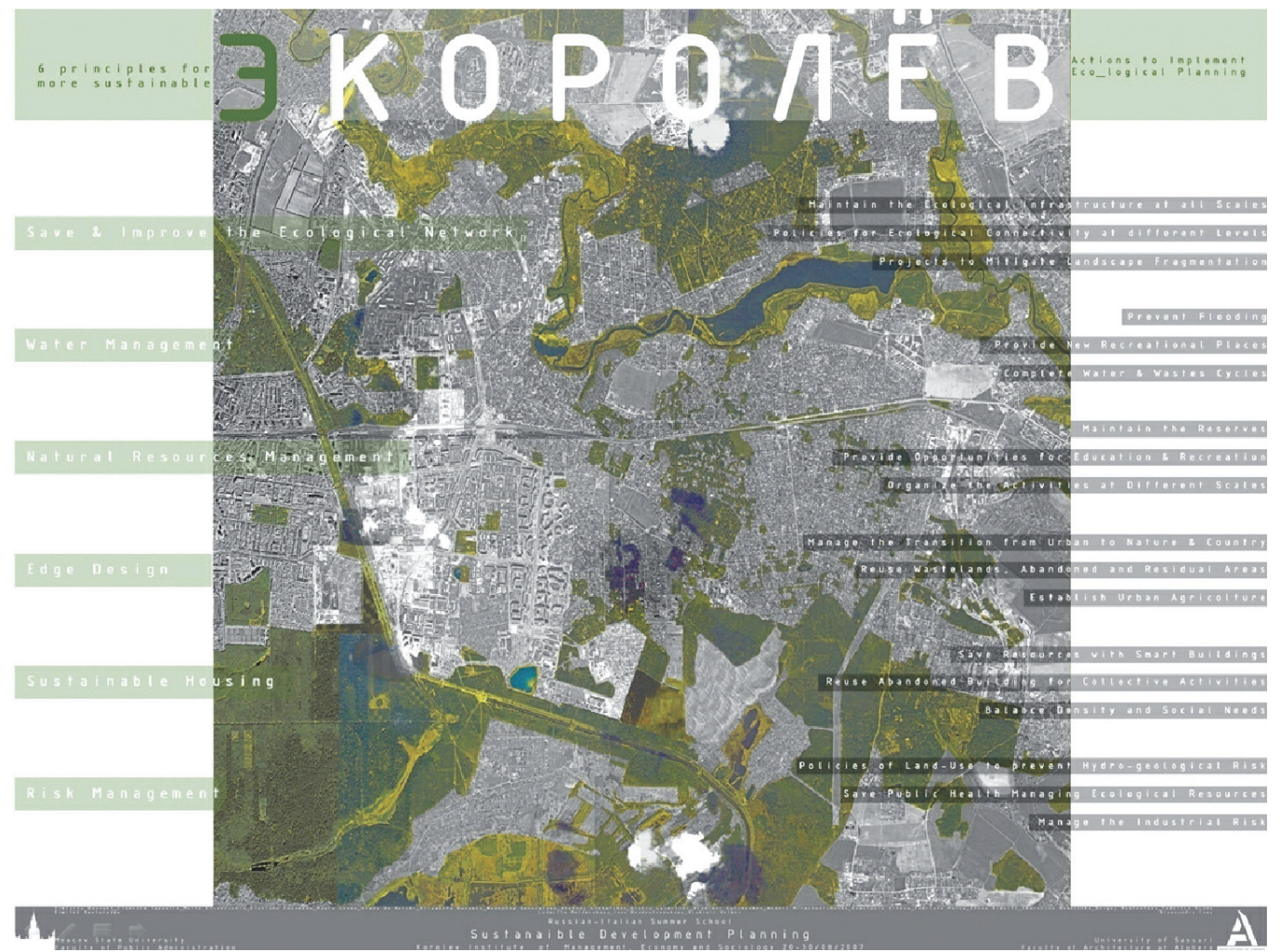

The main theme is the resources management:

- for natural resources, this is addressed in talking about Losiniy Ostrov Natural Park and its edge in touch with the urban fabric, and talking about connectivity;

- for energy, this is addressed in talking about sustainable housing, paying attention to bio-climatic design, and to the life cycle of buildings, infrastructure and urbanized land;

- for materials, paying attention to the lifecycle and the system dynamics related to waste production;

- for water, it is treated in small catchment areas - that provide not only sustainable drainage, but also recreational areas - and with waste-water treatment plants that can also provide areas for educational and recreational purposes

The second topic is the safety of population, treated using risk management:

- for industrial heavy metal pollution, mainly using the green infrastructure to mitigate it;

- $\quad$ for flooding - which should be strongly considered in the face of global Climate Change (IPCC, 2014) - by designing a network of channels, paths for the water, and places to accumulate it, also providing recreational areas surrounded by new more sustainable districts 


\section{The real results: local responses}

The final project was submitted to the mayor and the administration, experts, students and teachers from several Moscow region high schools, and was published bilingually in Moscow the following year once the practice part in Sardinia had been completed. The EKorolëv project was also presented at several conferences, professional meetings and the architecture biennial.

The large scale of the EKorolëv project and its multi-dimensional presentation gave both theoretical and instrumental results:

- The EKorolëv project demonstrates an ensemble of principles that need to be implemented simultaneously: "one by one" tactics bring more conflicts than results.

- Urbanization is maybe the most complex system created by humans: the transformation of such systems needs to be firstly modeled, and the best scenario with the lowest risk should be chosen.

- EKorolëv is a project with low ecological risks in the long term and could be used as a prototype of the ecopolis mode of urbanization.

- EKorolëv states that a coherent co-evolution of society and nature is possible and needs to be scientifically modeled and implemented in regional and urban planning, as in human way of life and everyday philosophy and practice.

- In the given conditions Russia needs to design strategies of urbanization and choose an ecological mode for new and old cities.

"Humanity is not able to jump out from Nature" (N. Baransky motto), "Build inclusive, safe and sustainable cities and human settlements" (IIS, 2014): towns need to take care of nature, as it was underlined in the UN GA in 2015. 


\section{REFERENCES}

1. Antonini, A. (2010). La Sostenibilidad de la Ciudad Histórica Turística (PhD Thesis), Unesco Chair "Sostenibilidad, Tecnología y Umanismo". Catalunya: Universitat Politécnica de Catalunya.

2. Antonini, A. \& Cecchini, A. (2009). Territorial Policies for Tourism Policies in Historic Cities: Measure to Manage. Sustainable Architecture and Urban Devolpment. CSAAR, Jordan.

3. Arnulfi, G.L. \& Marini, M. (2010). Performance Analysis of a Wind Powered Gas Storage System. Proceedings of the ASME Turbo Expo 2010: Power for Land, Sea and Air (GT2010), Genoa.

4. Bacchini, F., Billeci, B., Dettori, M. \& Monsù Scolaro A. (2012). Processes of Reuse of Historic Building Heritage between Conservation and Sustainability. Experiences in Interior Areas of Sardinia. In: O. Niglio (ed.). Paisaje Cultural Urbano e Identitad Territorial, Rome: Aracne, pp. 881-891.

5. Beckerman, W. (1972). Economists, Scientists and Environmental Catastrophe. Oxford Economic Papers, vol. 24, n. 3, pp. 327-334.

6. Blecic, I., Cecchini, A., Falk, M., Marras, S., Pyles, R.D., Spano, D.E.I. \& Trunfio, G.A. (2011). Towards a Planning Decision Support System for Low-Carbon Urban Development. In: Computational Science and its Applications: International Conference, ICCSA 2011: proceedings. Part I, Dordrecht: Springer, pp. 423-438.

7. Blecic, I., Cecchini, A. \& Talu, V. (2013). The Capability Approach in Urban Quality of Life and Urban Policies: Towards a Conceptual Framework. In: S. Serreli (ed.). City Project and Public Space. Dordrecht: Springer, pp. 269-288.

8. Boulding, K. (1966). The Economics of the Coming Spaceship Earth. In: H. Jarret (ed.), Environmental Quality in a Growing Economy. Baltimore M.D.: John Hopkins Pres, pp. 3-14.

9. Brudny, A. \& Kavtaradze, D. (1981). Ecopolis. Principles and Problems. Pouschino: ONTI (in Russian).

10. Brudny, A. \& Kavtaradze, D. (1985). The Coherent Development of the Nature and the Society. The International Exposition, Tsukuba, Japan. Moscow: Vneshtorgisdat.

11. Bulla, E., Casu, A., Doneddu, M., Floris, G., Fonnesu, A., Marini, M., Spanedda, F. \& Spanu, S. (2012). "Ville d'Alghero", in Marittimo - IT FR - Maritime. Progetto Case Mediterranee, Genoa: Sagep, pp. 20-23, 46-54.

12. Butler, D. \& Parkinson, J. (1997). Towards Sustainable Urban Drainage. Water Science and Technology, vol. 35, n. 9, pp. 53-63.

13. Cannaos, C. (2010). Identifying Urban Populations. A Conceptual Frame Work. In: G.Ruggeri and F. Trapani (eds.), Proceedings of the 3rd IRT International Scientific Conference. Vol. II, Palermo: Gulotta, pp. 745-754. 
14. Casu, A. (2011). Approaches to Sustainable Planning. In: D.N. Kavtaradze and A. Casu (eds.). 3Korolëv. Projects of Regional Sustainable Development. The Report on Russian-Italian and Italian- Russian Student Workshops in 2007-2008. Educational monograph, UN Decade «Education for Sustainable Development», Moscow: Acropol.

15. Casu, A. (2013). Space for Plural Publics and Their Involvement: Reflections on Some Strategic Planning Experiences. In: S. Serreli (ed.). City Project and Public Space. Dordrecht: Springer, pp. 259-267.

16. Cecchini, A. (2009). Which Tourism? Which Territories? In: G. Maciocco and S. Serreli (eds.). Enhancing the City: New Perspectives for Tourism and Leisure, Dordrecht: Springer, pp. 283-312.

17. Chambers, N., Simmons, C. \& Wackernagel, M. (2001). Sharing Nature's Interest: Ecological Footprints as an Indicator of Sustainability. London: Earthscan.

18. Clark, D.A. (2006). The Capability Approach: its Development, Critiques and Recent Advances. Institute for Development Policy and Management, University of Manchester, UK.

19. Costanza, R. (ed.) (1991). Ecological Economics: the Science and Management of Sustainability. NYC: Columbia U.P.

20. D’Ambrosio, D., Di Gregorio, S., Spataro, W. \& Trunfio, G.A. (2006). A Model for the Simulation of Forest Fire Dynamics Using Cellular Automata. Proceedings of the IEMSS Third Biennial Meeting: Summit on Environmental Modelling and Software.

21. D’Ambrosio, D., Filippone, G., Rongo R., Spataro, W. \& Trunfio, G.A. (2012). Cellular Automata and GPGPU: An Application to Lava Flow Modeling. International Journal of Grid and High Performance Computing, vol. 4, n. 3, pp. 30-47.

22. Daly, H. (1977). Steady-State Economics: the Economics of Biophysical Equilibrium and Moral Growth. San Francisco: Freeman.

23. Daly, H. (1996). Beyond Growth. The Economics of Sustainable Development. Boston: Beacon Press.

24. Daly, H.E. (1990). Toward Some Operational Principles of Sustainable Development, Ecological Economics, n. 2, pp. 1-6.

25. Daly, H.E. (1992). Operationalizing Sustainable Development by Investing. Natural Capital, ISEE Conference, Stockholm.

26. Dasgupta, P. \& Heal, D. (1979). Economic Theory and Exhaustible Resources. London: Cambridge U.P.

27. De Jouvenel. B. (1965). Pour une Conscience Ecologique. In : Id. (1968). Arcadie, Essais sur le Mieux Vivre. Paris: Futuribles, pp. 236-248.

28. Deelstra, T. (1988). Public Participation in Improving Urban Life and Environment, In: Cities and Ecology. MaB Program. Collected reports. Suzdal, USSR, vol. 2, pp. 153-167. 
29. Delitala, A., Marini, M., Satta, A. \& Spanedda, F. (2001). Wind Farm Planning Evaluation: Case Study in Sardinia Combining Engineering, Community and Landscape Requirements. Wind Engineering, vol. 25, n. 3, pp. 161-170.

30. Friedmann, J. (1992). Empowerment: The Politics of Alternative Development. Oxford: Blackwell.

31. Gagarina, L.G., Kavtaradze, D.N., Mordovin, A.A., Portnov, E.M., Slyusar \& Kyaw Zaw Ye V.V. (2015). Modeling of a Dynamic Interaction of Motor Transport and Natural Systems in Order to Minimize the Risks of Project and Management Decisions. Computer Science, vol. 11, n. 2, pp. 297-303.

32. Gazzano, R., Marini, M. \& Satta, A. (2010). Semi-Empirical Methods for the Analysis of Vertical Axis Wind Turbines with Helical Blades. Proceedings of the ASME Turbo Expo 2010: Power for Land, Sea and Air (GT2010), Genoa.

33. Georgescu, Roegen N. (1972). The Entropy Law and the Economic Process. Cambridge, MA: Harvard U.P.

34. Gerzberg, L. (2015). Ecosettlements in Russia. In: Public Administration: Russian Federation in Modern World, International Conference. School of Public Administration. Moscow: Moscow State University (in print).

35. Grossman, G.M. \& Krueger A.B. (1995). Economic Growth and the Environment. Quarterly Journal of Economics, n. 10, pp. 353-377.

36. Immler, H. (1993). Welche Wirtschaft Braucht die Natur? Mit Ökonomie die Ökokrise lösen. Frankfurt: Fischer Verlag.

37. Hui, C. (2006). Carrying Capacity, Population Equilibrium, and Environment's Maximal Load. Ecological Modelling, n. 192, pp. 317-320.

38. Ignatieva, M. \& Ahrné, K. (2013). Biodiverse Green Infrastructure for the 21st Century: From «Green Desert» of Lawns to Biophilic Cities. Journal of Architecture and Urbanism, vol. 37, n. 1, pp. 1-9.

39. International Institute for Sustainable Development (IIS D). (2014). A Reporting Service for Environment and Development Negotiations. Earth Negotiations Bulletin, vol. 32, n. 12, p. 17.

40. IPCC (2014). Climate Change 2014: Impacts, Adaptation, and Vulnerability. Part A: Global and Sectoral Aspects. Contribution of Working Group II to the Fifth Assessment Report of the Intergovernmental Panel on Climate Change [Field, C.B., V.R. Barros, D.J. Dokken, K.J. Mach, M.D. Mastrandrea, T.E. Bilir, M. Chatterjee, K.L. Ebi, Y.O. Estrada, R.C. Genova, B. Girma, E.S. Kissel, A.N. Levy, S. MacCracken, P.R. Mastrandrea, and L.L. White (eds.)]. Cambridge, United Kingdom and New York, NY, USA: Cambridge University Press.

41. Kavtaradze, D. (2015). Business and Simulation Games in University Education, Economics and Business, vol. 8, n. 2, pp. 106-116.

42. Kavtaradze, D.N. \& Casu, A. (eds.) (2011). E. Korolëv. Projects of Regional Sustainable Development. The report on Russian-Italian and Italian-Russian Student Workshops in 2007-2008. Educational monography. UN Decade «Education for Sustainable Development», Moscow: Acropol. 
43. Kavtaradze, D.N. \& Likhacheva, E.Yu. (2012). Sustainable Development: From Concepts to Models. In: Shmelev, I. Shmeleva (eds.). Sustainability Analysis: an Interdisciplinary Approach, Hampshire, Great Britain: Palgrave Macmillan, pp. 149-178.

44. Kavtaradze, D., Lychkina, N. \& Volkov V. (2010). System Dynamics Simulation Modeling as the Tool in Urban and Ecological Network Biodiversity Management URBIO2010. In: Proceedings of the $2^{\text {nd }}$ International Conference of Urban Biodiversity and Design. Kioto, Japan, 18-22 May, 2010, p. 59.

45. Knees, A., Ayres, R.U. \& D’Arge, R.C. (1970). Economics and the Environment. Washington DC: Resource for the Future.

46. Linton, J. (1998). Beyond the Economics of More: the Place of Consumption in Ecological Economics, Ecological Economics, n. 25, pp. 239-248.

47. Martinez, A.J., Roca, J.J. (2000). Economia Ecológica y Politica Ambiental. PNUMAFCE.

48. Martinez, A.J., Schlupmann, K. (1984). L'Ecologisme i l'Economia. Història d'unes Relacions Amagades. Barcelona: Edicions 62.

49. Meadows, D.H., Meadows, D.L., Randers, J. \& Behrens, W.W. III (1972). The Limits to Growth, NYC: Universe Books.

50. Mostafavi, M. (ed.) (2004). Landscape Urbanism. London: AA Publications.

51. Munasinghe, M. (1999). Is Environmental Degradation an Inevitable Consequence of Economic Growth? Ecological Economics, n. 29, pp. 89-109.

52. Muñoz, F. (2008). Urbanalització: Paisajes Comunes, Lugares Globales. Barcelona: Gustavo Gili.

53. Norberg-Schultz C. (1998). The Concept of Dwelling. On the Way to a Figurative Architecture, NYC: Rizzoli-Electa.

54. Numata, M. (1988). Water-oriented Approach to Urban Ecosystems, In: Cities and Ecology. MaB Program. Collected reports. Suzdal, USSR, n. 2, pp. 39-46.

55. Nussbaum, M. (1999). Women and Equality. The Capability Approach. International Labour Review, vol. 138, n. 3, pp. 227-245.

56. Oke, T.R. (1973). City Size and the Urban Heat Island. Atmospheric Environment, vol. 7, n. 8, pp. 769-779.

57. Passet, R. (1996). L'Economique et le Vivant. Paris: Economica.

58. Pearce, D.W., Kerry Turner, R. (1990). Economics of Natural Resources and the Environment, NYC: Harvester Wheatsheaf.

59. Phipps, S. (2002). The Well-Being of Young Canadian Children in International Perspective: A Functionings Approach. Review of Income Wealth, vol. 48, n. 4, pp. 493-515.

60. Pigou, A.C. (1999). The Economics of Stationary States. London: MacMillan. 
61. Pittaluga, P. (2008). Images of Local Societies and Projects for Space. In: G. Maciocco (ed.). Urban Landscape Perspectives. Dordrecht: Springer, pp. 87-104.

62. Plaisant, A. (2013). Eight Proposals to Construct the Democratic City of the New Millennium. In: S. Serreli (ed.). City Project and Public Space. Dordrecht: Springer, pp. 259-267.

63. Russell, J. S. (2001). Landscape Urbanism: It's the Future, not a Contradiction. Architectural Record, August.

64. Ruth, M. (1993). Integrating Economics, Ecology and Thermodynamics. Dordrecht: Kluwert.

65. Sayre, N.F. (2008). The Genesis, History, and Limits of Carrying Capacity. Annals of the Association of American Geographers, n. 98, pp. 120-134.

66. Sen, A.K. (1993). Capability and Well-Being. In: Id. and M. Nussbaum (eds.). The Quality of Life. Oxford, MA: Clarendon, pp. 9-29.

67. Sen, A.K. (1999). Development as Freedom. NYC: Knopf.

68. Solow, R. \& Stiglitz, J.E. (1997). Reply. Ecological Economics, vol. 22, n. 3, pp. 267-269.

69. Spanedda, F. \& Serra, A. (2007). Energy Refurbishment in the City Center of Osilo, Sardinia (Italy). IV International Conference on Sustainable Architectural Design and Urban Planning. Conference proceedings, Vietnam.

70. Sukopp, H. \& Henke, H. (1988). Nature in Towns: A Dimension Necessary for Urban Planning Today. In: Cities and Ecology. MaB Program, Suzdal, USSR, Collected reports. Vol. 2, pp. 30-36.

71. Tjallingii, S. K. (2000). Ecology on The Edge: Landscape and Ecology between Town and Country. Landscape and Urban Planning, vol. 48, n. 3-4, pp. 103-119.

72. Trunfio, G.A. (2004). Predicting Wildfire Spreading Through a Hexagonal Cellular Automata Model. In: ACRI 2004: 6th International Conference on Cellular Automata for Research and Industry, Amsterdam: Springer, pp. 385-394.

73. Vivien, F.D. (1994). Economie et Ecologie. Paris: La Decouverte.

74. Wackernagel, M., Rees, W.E. (1995). Our Ecological Footprint. Reducing Human Impact on the Earth. Gabriola Island, BC: New Society Publishers.

75. Waldheim, C. (ed.) (2006). The Landscape Urbanism Reader. Princeton Architectural Press. 